\title{
Accounting
}

\section{The role of profitability in moderating the factors affecting transfer pricing}

\author{
Niswah Baroroh ${ }^{a^{*}}$, Suryani Malik ${ }^{\mathrm{a}}$ and Kuat Waluyo Jati ${ }^{\mathrm{a}}$
}

${ }^{a}$ Department of Accounting, Faculty of Economics, Universitas Negeri Semarang, Indonesia

\begin{tabular}{l}
\hline C H R O N I C L E \\
\hline Article history: \\
Received: January 1, 2021 \\
Received in revised format: \\
January 23 2021 \\
Accepted: February 10, 2021 \\
Available online: \\
February 10, 2021 \\
\hline Keywords: \\
Transfer pricing \\
Tax expense \\
Bonus mechanism \\
Tunneling incentive \\
Profitability
\end{tabular}

\section{A B S T R A C T}

\begin{abstract}
This study aims to analyze the influence of tax expense, bonus mechanism, and incentive tunneling on transfer pricing with profitability as moderating. The population is mining companies listed on the Indonesia Stock Exchange in 2016- 2019. The sample selection used a purposive sampling technique and obtained 45 analysis units. Data analysis method used moderated regression analysis (MRA). The study showed that tunneling incentive had a significant positive on transfer pricing decision. Tax expense and bonus mechanism had no significant effect on transfer pricing decisions. Profitability strengthened the effect of tax expense on transfer pricing decisions. However, profitability was unable to moderate the influence of bonus mechanism and tunneling incentive towards on transfer pricing decisions. The conclusions are that shareholders the majority of a controlled by the foreign shown to improve the transfer pricing decision. An increase in profitability followed the transfer pricing decision high to reduce tax expense in the company.
\end{abstract}

(C) 2021 by the authors; licensee Growing Science, Canada

\section{Introduction}

Economic development and technology sophistication resulted in easier activities transactions between countries. This makes the company want to expand its business by establishing subsidiaries in other countries to strengthen its business strategy and develop the company's products in various countries. However, a problem will be faced by the company and subsidiaries in different countries, the difference tax rates in any country. Due to the difference in tax rates, companies tend to shift profits to companies in other countries with lower tax rates that still have a special relationship. These efforts can be done by means of transfer pricing. Transfer pricing is an engineering method to manipulate prices systematically which aims to reduce the net profit companies, make as if loss to avoid tax in the state of the country has a lower tax rate where the company still has a special relationship (Rachmat, 2019). The existence of transfer pricing activities between companies results in reduced tax revenue in a country. According to the Executive Director Center for Indonesian Taxation, Indonesia has the potential to lose Rp 100 trillion each year because of the practice of transfer pricing from multinational companies which aims to minimize tax deposits to the country (economy.okezone.com, 2015). The case of transfer pricing in Indonesia, PT Adaro Energy Tbk in the years 2009-2017. Adaro conducts transfer pricing to one of the children Companies in Singapore namely Coal trade Service International Pte Ltd. Adaro sells coal to Coal trade with prices low. Then, Coal trade sold the coal again at a higher price (tirto.id, 2019). The phenomena above showed the company wants to remain maximize profit with reducing tax expense. Companies can make transfer pricing decisions with various factors, namely tax factors and non-tax factors. So, these reasons make the authors interested in using these two factors, namely: tax expense, bonus mechanisms, and tunneling incentives.

* Corresponding author

E-mail address: nbaroroh.unnes@gmail.com (N. Baroroh) 
The study about effects of tax expense to the transfer pricing decision is still showing inconsistent results. The tax is mandatory contributions from people who are given to the country are forced based on law and do not receive direct contra-achievement (Anisyah, 2018). The company takes a strategy to minimize tax expense in countries with high tax rates (Alino \& Lane, 2015). The bonus mechanism is a reward to the manager from the owner company because meeting predetermined performance targets. Managers get a bonus based on the increased net profit in the company (Anisyah, 2018). Research on the bonus mechanism has shown inconsistent. Research on the effect of tunneling incentives on transfer pricing decisions still shows inconsistent results, (Lo et al., 2010; Sundari \& Susanti, 2016; Susanti \& Firmansyah, 2018; Anisyah, 2018). Ownership structure concentrated on one owner will cause agency conflicts between majority shareholders and minority shareholders (Hartati et al., 2015). Majority shareholders can make decisions for their personal interests, without thinking about minority shareholders (Saifudin \& Putri, 2018). The purpose of this study was to determine the effect of tax expense, bonus mechanisms, and tunneling incentives on transfer pricing decisions and the role of profitability as moderation between tax expense, bonus mechanisms, and tunneling incentives on transfer pricing decisions. Profitability chosen as a moderating variable because based on previous research has an effect on transfer pricing decisions (Richardson et al., 2013; Agana et al., 2018; Anisyah, 2018). Profitability as variable moderation becomes the originality this study period 2016-2019. This study uses two theories, namely agency theory is used to understand concepts tax expense and tunneling incentives. Then Accounting Positive Theory is used to understand concept bonus mechanisms.

This study uses a sample of mining companies listed on the Indonesia Stock Exchange (BEI). Mining companies are selected as samples because their capital mining companies are dominated by foreign capital and have overseas subsidiaries, so this indicates a special relationship. So, the mining sector has a tendency to do the transfer pricing.

\section{Literature Review and Hypothesis Development}

Theory that underlies the research is agency theory and accounting positive theory. Jensen and Meckling (1976) describe agency theory as the relationship between management (agent) and shareholders (principal). Ang et al. (2000) stated that ownership structure can influence the emergence of agency problems between shareholders and managers. When a company has a concentrated ownership structure, agency problems that will emerge are different, where the problems between managers and shareholders will change become majority shareholders and minority shareholders (Jafri \& Mustikasari, 2018). Agency theory also explains the relationship between taxpayers and tax authorities. Reinganum and Wilde (1985) explain that taxpayers can also be seen as agents. The relationship between agent and principal occurs between taxpayer or company and the tax authorities. The role of the taxpayer is to report and pay taxes to the government, while the role of the tax authorities is to collect taxes. Watts and Zimmerman (1986) explain accounting positives theory are making policies of accounting which can cause problems for the company and the parties concerned with the financial statements. Bonus plan hypothesis is one of which describes accounting positive theory. In accordance with the bonus plan hypothesis, the manager takes profit maximizing action in the current year for his own benefit, namely obtaining a bonus. Even though transfer pricing has been regulated in taxation regulations, the actions of managers who prefer accounting policies for their own benefit will certainly harm state revenues by means of taxes if it is carried out beyond reason. The tax expense is a tax that is charged to the individual or entity that is coercive, is used for state income and does not receive direct reciprocity (Anisyah, 2018). Companies that are in countries with high tax rates will shift their profits to countries that have lower tax rates (Rachmat, 2019). This encourages companies to carry out transfer pricing to minimize the tax expense that must be paid (Graham et al., 2017). Based on agency theory, problems can occur between taxpayer or company and tax authorities (Reinganum \& Wilde, 1985). Taxpayers must report and pay their income taxes, while the role of the tax authorities is to collect taxes and want high tax revenues by calculating corporate income tax in accordance with taxation provisions. The height of tax expense to be paid by the company, the higher the company's efforts to minimize right tax. This research is supported by Alino \& Lane (2015), Anisyah (2018), and Rachmat (2019). The results show that tax expense has a positive effect on transfer pricing decisions. So, it can be said that the higher tax expense borne by the company, the higher the possibility for the company to make a transfer pricing decision.

\section{$\mathrm{H}_{1}$ : Tax expense has a positive effect on transfer pricing decisions.}

Bonus mechanism is the way the most popular reward is given by the owner to the manager company because it has reached the target performance. Managers will be affected to manipulate profit companies in order to obtain the maximum bonus (Nuradila \& Wibowo, 2018). The strategy used by managers in order to obtain the bonus is to increase net profits of companies as a whole by using a calculation accounting. Bonus plan hypothesis is one of the hypotheses of accounting positive theory that describes the relationship between the profit and bonus. The bonus mechanism which is seen by the trend of net income will affect the transfer pricing decision. The company owner will see the performance of the directors in providing bonuses. As an assessment of the performance of the board of directors, the owner of the company will see the company's overall profit. So, the directors will try to make the company's overall profit have increased, including by way of doing transfer pricing. Transfer pricing is carried out by transferring the profits of companies that are in countries with high tax rates to companies that are in countries with low tax rates. Transfer pricing is carried out to reduce the tax expense of the entire company, so that the company's overall net profit will be higher than not performing transfer pricing. According to Lo et al. (2010) a manager companies tend to take advantage of transfer pricing to maximize the bonus received when bonuses are awarded based on the achievement of net profit after tax companies. Then, if income net after tax 
which acquired the company as a whole in accordance with the target desired owners of the company, then it will be an even better image of the manager in the eyes of the owner companies and increasingly high potential to earn bonuses. This research is supported by Saifudin and Putri (2018) and Rachmat (2019) that the bonus mechanism has a positive effect on the company's decision to do transfer pricing.

\section{$\mathrm{H}_{2}$ : The bonus mechanism has a positive effect on transfer pricing decisions.}

Tunneling incentive according to Hidayat et al. (2019) is the majority shareholder of the transfer of assets and profit of the company, but the holders of shares of minority come to bear his burden. The practice of tunneling incentives includes not distributing dividends, selling company assets at a lower price than the supposed price to controlling shareholders or companies controlled by controlling shareholders. Agency theory, conflict agency may occur between majority shareholders and minority shareholders (Jafri \& Mustikasari, 2018). Conflicts have occurred, holders of shares majority impose any wishes to the manager for the benefit of the private. Due to her, companies with easy to perform acts negatively as do transfer pricing. Transfer pricing is easily done through efforts to move assets or income that is owned by the company, so that profits are generated companies become lower. Activity tunneling was done by holders of shares; the majority of lead is not the division of dividend so that holders of shares of minority feel less advantaged. The transfer of assets or income that is generated will decrease the profits obtained by holders of shares of a minority, so that they are experiencing a decrease in the welfare of the company (Jafri \& Mustikasari, 2018). Practice to remove assets or income that is done by the manager as a result of encouraging majority shareholders is the trigger of the main occurrence of transfer pricing. This is supported by Chan et al. (2016) which states that tunneling can be caused by majority shareholder ownership. This research is supported by Lo et al. (2010), Sundari and Susanti (2016), and Anisyah (2018) results show that tunneling incentives have a positive effect on indications of transfer pricing. Measures tunneling incentive will make the holders of shares majority get benefit more, so that they will put pressure on the company's management to carry out acts of transfer pricing. Tunneling incentives are proxied by share ownership by foreign parties, the greater the share ownership by foreigners, the greater the likelihood of companies moving their assets to other countries to avoid taxes, one of which is through transfer pricing.

\section{$\mathrm{H}_{3}$ : Tunneling incentive has a positive effect on transfer pricing decisions.}

Profitability is one way to measure company performance which describes the company's ability to generate profits for a certain period (Anisyah, 2018). Companies that have a high amount of profit indicate that the company is considered to have good prospects. Richardson et al. (2013) stated that the higher the profit the company receives, the higher the income tax borne by the company will trigger the company to make a transfer pricing decision. When a company makes a transfer pricing decision, the company will reduce its profit in a country with a high tax rate to a country that has a low tax rate. Agency theory explains the problems that can occur between taxpayers or companies and tax authorities (Reinganum \& Wilde, 1985). Taxpayers are obliged to pay their tax expense, while companies want high profit income by minimizing their tax expense. However, the tax authorities or the government want high corporate income tax by calculating corporate taxes according to the tax corridors. Then, companies that have a high level of profitability, will take the decision of transfer pricing in order to lower the tax expense.

\section{$\mathrm{H}_{4}$ : Profitability moderates the effect of tax expense on transfer pricing decisions.}

Companies that have a high level of profitability will tend to make transfer pricing decisions to maximize bonuses from the company owners. Giving bonuses to company management is one of the accounting strategies to increase company profits in the current period (Hartati et al., 2015). The bonus mechanism itself is the most popular way used by company owners to reward company management. So, it is logical that if the bonus is given based on the increase in profit for each period, the management will make changes in reported earnings. The high rate of profitability that is higher than the bonus will be given to the management companies also high because of bonuses awarded based on the increase in profit net (Lo et al., 2010). The bonus mechanism which is seen by the trend of net income will affect the transfer pricing decision. The company owner will see the performance of the directors in providing bonuses. As an assessment of the performance of the company's directors, the owner of the company will see the company's overall profit. Then, the directors will try to make the company's overall profit have increased, including by way of doing transfer pricing. Transfer pricing is carried out by transferring the profits of companies that are in countries with high tax rates to companies that are in countries with low tax rates. Transfer pricing is carried out to reduce tax expense of the entire company, so that the company's overall net profit will be higher than not carrying out transfer pricing. So, companies with a high level of profitability tend to make transfer pricing decisions so that the bonuses received by the company are high.

\section{Hs: Profitability moderates the effect of the bonus mechanism on transfer pricing decisions.}

According to Hartati et al. (2015) tunneling incentives are ownership structures that result in agency conflicts between majority shareholders and minority shareholders. This is in accordance with the agency theory expressed by Jafri \& Mustikasari (2018) where 
the problem that will arise is an agency conflict, namely between the majority shareholder as controlling shareholder and minority shareholder as non-controlling shareholder. The majority shareholder transfers the company's assets or profits to other subsidiaries that are still under its auspices. Meanwhile, minority shareholders feel disadvantaged because it only benefits the majority shareholder and there is no dividend distribution (Lo et al., 2010). The desire of the majority shareholder to obtain high profits, the higher the willingness of shareholders to make transfer pricing decisions, namely by transferring profits from companies located in countries with high tax rates to countries with low tax rates. This aims to reduce the tax expense that is paid when the profit earned by the company is high, so that later the net profit after tax from the entire company is still high. Then, companies that have a high level of profitability tend to make transfer pricing decisions made by controlling shareholders in conducting company tunneling incentives.

\section{H6: Profitability moderates the effect of tunneling incentives on transfer pricing decisions.}

\section{Research Methods}

The population in the study this is the company's sector of mining which is listed on the Stock Exchange Indonesia (BEI) in the period from 2016-2019 with the number of 47 companies. Selection of the sample using the technique of purposive sampling and acquired 16 companies with 45 units of analysis are described in Table 1. Testing the hypothesis is done with moderated regression analysis using the test value of the difference absolute uses IBM SPSS 23.

\section{Table 1}

Sampling

\begin{tabular}{|c|c|c|}
\hline Sample Criteria & Elimination & Amount \\
\hline $\begin{array}{l}\text { Companies mining are listed on Indonesia Stock Exchange in } 2019 \\
\text { Less: }\end{array}$ & & 47 \\
\hline Mining companies are not listed on Indonesia Stock Exchange in a row during the years 2016-2019 & (3) & 44 \\
\hline Companies that suffered losses during the years $2016-2019$ & (14) & 30 \\
\hline Companies that receive the benefit of tax during the years $2016-2019$ & $(5)$ & 25 \\
\hline $\begin{array}{l}\text { Companies that do not reveal the data share ownership of foreign and total shares outstanding in a row during the } \\
\text { years 2016-2019 }\end{array}$ & (7) & 18 \\
\hline Companies that do not disclose the transaction to the related assets and liabilities in a row during the year $2016-2019$ & (2) & 16 \\
\hline Number of sample companies & & 16 \\
\hline Number of research analysis units ( 4 years x 16 companies) & & 64 \\
\hline The eliminated outliers from the sample & (19) & 45 \\
\hline Total final unit of analysis research for years 2016-2019 & & 45 \\
\hline
\end{tabular}

Source: Data Secondary were processed, 2020

The dependent variable in the study is transfer pricing, while the independent variables used are tax expense, bonus mechanism and tunneling incentives. This study also uses a moderating variable, namely profitability. An explanation of the operational definitions of each variable used in the study is in Table 2.

\section{Table 2}

Operational definition of variables

\begin{tabular}{|c|c|c|c|}
\hline No. & Variable Name & Operational Definition & Measurement \\
\hline 1. & Transfer Pricing (RPTAL) & $\begin{array}{l}\text { The mechanism used by companies to transfer company } \\
\text { profits from countries with high tax rates to companies in } \\
\text { countries with lower tax rates that still have a special } \\
\text { relationship (Susanti \& Firmansyah, 2018) }\end{array}$ & $\begin{array}{l}\text { RPTAL }=\frac{\text { RPT Aset }+ \text { RPT Liabilitas }}{\text { Ekuitas }} \times 100 \% \\
(\text { Utama, 2015) }\end{array}$ \\
\hline 2. & Tax Expense (GAAP ETR) & $\begin{array}{l}\text { Taxes charged to individuals and entities that are used as one } \\
\text { of the state's revenues (Anisyah, 2018) }\end{array}$ & $\begin{array}{l}\text { GAAP ETR }=\frac{\text { total tax expense }}{\text { Profit before tax }} \\
\text { (Alfandia, 2018) }\end{array}$ \\
\hline 3. & $\begin{array}{l}\text { Bonus Mechanism } \\
\text { (ITRENDLB) }\end{array}$ & $\begin{array}{l}\text { Compensation or rewards given to company management for } \\
\text { success because they have met the targets set by the } \\
\text { company (Rachmat, 2019) }\end{array}$ & $\begin{array}{l}\text { ITRENDLB }=\frac{\text { Net income for year } \mathrm{t}}{\text { Net income for year } \mathrm{t}-1} \times 100 \% \\
\text { (Nuradila \& Wibowo, 2018) }\end{array}$ \\
\hline 4. & Tunneling Incentive (KA) & $\begin{array}{l}\text { Majority shareholders to transfer the assets and profits of } \\
\text { companies that aims to gain the advantage of their own, but } \\
\text { minority shareholders come to bear the burdens incurred } \\
\text { (Nuradila \& Wibowo, 2018) }\end{array}$ & $\begin{array}{l}\text { Foreign ownership }= \\
\text { number of foreign shareholdings } \\
\text { Number of shares outstanding } \\
\text { X } 100 \% \\
\text { (Septiyani et al., 2018) }\end{array}$ \\
\hline 5. & Profitability (ROE) & $\begin{array}{l}\text { One of the measurements for company performance that } \\
\text { describes the company's ability to generate profits during a } \\
\text { certain period at the level of sales, assets owned and share } \\
\text { capital (Anisyah, 2018) }\end{array}$ & $\begin{array}{l}\text { ROE }=\frac{\text { Net income after tax }}{\text { Total Equity }} \\
\text { (Khasanah, 2015) }\end{array}$ \\
\hline
\end{tabular}


The data analysis techniques used to test the hypothesis in this study were descriptive statistics, classical assumption tests, and hypothesis testing. Testing the research hypothesis using moderation regression analysis with a significance level of 0.05 . The multiple regression equation is shown in Eq. (1).

$$
\begin{aligned}
& \text { RPTAL }=\alpha+\beta_{1} \text { GAAP ETR }+\beta_{2} \text { ITRENDLB }+\beta_{3} \text { KA }+\beta_{4} \mid \text { GAAP ETR-ROE }\left|+\beta_{5}\right| \text { ITRENDLB-ROE }\left|+\beta_{6}\right| \text { KA- } \\
& \text { ROE } \mid+\mathrm{e}
\end{aligned}
$$

\section{Results and Discussion}

The results of the analysis of statistics descriptive indicate a variable tax expense, bonus mechanism, tunneling incentive, and profitability has values mean more substantial than the value of the standard deviation so that the spread of the data homogeneous. It is demonstrated that the company one by one does not have different data. While the value of the mean at a variable transfer pricing is smaller than the value of the standard deviation so that the spread of data is called heterogeneous. Test the assumptions of classical used to ensure that the samples are used free from interference multicollinearity, heteroskedasticities and autocorrelation (Ghozali, 2016). The normality test used the Kolmogorov-Smirnov one-sample test with a significance value of 0.073 is greater than the significance level of 0.05 so that the research data is normally distributed. The multicollinearity test shows the result that there is no multicollinearity because each variable has a value tolerance $>0.1$ and VIF $<10$. Heteroskedasticities test with white test does not cause a problem heteroskedasticities because $c^{2}$ count $<\mathrm{c}^{2}$ table $(13.095<60.480)$ with the value of trust 0.05 . The autocorrelation test results use the Run Test with the Asymp value. Sig. $(2-$ tailed) of 0.071 with a significance of 0.05 so it can be said that there is no autocorrelation in the regression model. The result of the hypothesis test on the ANOVA test has a significance value of 0.006 and $<0.05$, so it can be said that the regression model can be used to predict the effect of tax expense, bonus mechanisms, and tunneling incentives as well as interactions on profitability variables simultaneously affect transfer pricing decisions. The results of the coefficient of determination indicates the value of Adjusted R Square of 0.264. It is demonstrated that the $26.4 \%$ of the transfer pricing variable in this study can be explained by the variation of the independent variable and $73.6 \%$ is explained by other variables outside the research model. The regression equation in the absolute difference test is seen in Eq. (2).

$$
\begin{aligned}
& \text { RPTAL }=0.015+(-0.095) \text { GAAP ETR }+0.009 \text { ITRENDLB }+0.105 \text { KA + } 0.025 \mid \text { GAAP ETR }- \text { ROE } \mid+(-0.014) \\
& \mid \text { ITREND-ROE }|+0.001| \text { KA-ROE } \mid+\mathrm{e}
\end{aligned}
$$

\begin{tabular}{|c|c|c|c|c|}
\hline Hypothesis & Statement & $\beta$ & Sig & Result \\
\hline $\mathrm{H}_{1}$ & Tax expense has a significant positive effect on transfer pricing decisions & -0.095 & 0.398 & Rejected \\
\hline $\mathrm{H}_{2}$ & The bonus mechanism has a significant positive effect on transfer pricing decisions & 0.009 & 0.435 & Rejected \\
\hline $\mathrm{H}_{3}$ & Tunneling incentive has a significant positive effect on transfer pricing decisions & 0.105 & 0.002 & Received \\
\hline $\mathrm{H}_{4}$ & Profitability moderated by significantly influence tax expense on transfer pricing decisions & 0.025 & 0.012 & Received \\
\hline $\mathrm{H}_{5}$ & Profitability moderated by significantly influence bonus mechanism on transfer pricing decisions & -0.014 & 0.381 & Rejected \\
\hline $\mathrm{H}_{6}$ & Profitability moderated by significantly influence tunneling incentive on transfer pricing decisions & 0.001 & 0.967 & Rejected \\
\hline
\end{tabular}

The results of testing the hypothesis of research presented in Table 3.

\section{Table 3}

Summary of Hypothesis Test Results

The statistical output on the effect of tax expenses on transfer pricing decisions showed that the beta value of - 0.095 with significant level $0.398>0.05$. Based on agency theory according to Reinganum and Wilde (1985), taxpayers can be seen as agents and tax authorities as principals. Where the taxpayer or company must report and pay taxes in accordance with predetermined tax calculations. However, taxpayers want the maximum profit to be obtained by reducing the tax expense they must pay. Meanwhile, the tax authorities want high tax revenues by calculating corporate income tax in accordance with statutory regulations. The research results prove that the tax expense has no effect on transfer pricing decisions. This means that the high tax expense that must be paid by the company does not influence the company to make transfer pricing decisions. This shows that companies tend to comply in paying their taxes in accordance with applicable tax regulations. In addition, due to tighter supervision from tax officials and the government, companies will be more careful and comply with regulations. So that in conducting tax savings, the method chosen is not in the form of transfer pricing, but other methods such as tax planning to streamline the way the tax expense to a minimum that is still in the frame regulations applicable tax. This research was supported by Saifudin and Putri (2018) and Susanti \& Firmansyah (2018).

In terms of the effect of the bonus mechanism on transfer pricing decisions, the results of the study show that bonus mechanisms do not affect transfer pricing decisions. This means that company management does not choose transfer pricing to maximize profit after tax in order to get a bonus from the company owner. The goal of earning a bonus but by presenting information that is not actual is highly unethical for a manager. Managers want the results of their performance to be assessed properly by 
presenting financial statements in accordance with actual conditions which can later be used for decision making. Bonus plan hypothesis is one of which described the accounting positive theory that be the relationship between bonus and profit. This prompted the management of the company to obtain a bonus high according to the company's net profit increase. As a result, managers want their performance results to get a good image, so professional managers will present financial reports in accordance with the actual situation which are not only for personal gain, but also pay attention to the quality of information produced as a form of credibility and professionalism. When a manager presents actual information and is accompanied by a good performance, it is possible that the manager will get a bonus for his performance. This research is in line with research conducted by Sundari \& Susanti (2016), Susanti \& Firmansyah (2018), Septiyani et al. (2018), and Anisyah (2018). The results of this study empirically prove that tunneling incentives have a positive effect on transfer pricing decisions. Agency theory assumes that there is a difference between the majority shareholder and the minority shareholder (Jafri \& Mustikasari, 2018). Majority shareholders have more information as compared to minority shareholders so it will be easier to control the management of the company.

The majority shareholder transfers the company's assets or profits to other subsidiaries that are still under its auspices for their own interests, while the minority shareholders feel disadvantaged because there is no dividend distribution (Lo et al., 2010). This is what motivates the majority shareholder to conduct tunneling incentives. When the ownership of shares owned by the foreign higher than it will make it easier to control the management company. This is done to reduce expenses that can reduce profits in the company, but with other intentions to enrich the majority shareholder. Desire of the majority shareholder to obtain high profits, making companies tend to be selecting transfer pricing that is to perform the transfer of profits of companies which are in countries with tax of rate higher to countries with tax of rate low. It aims to suppress the tax expenses paid, so that later on net profit after tax of the whole company are high. When the profit after tax is high, the tunneling incentives carried out by the majority shareholder will get bigger so that the greater the transfer pricing carried out by the majority shareholder. This research is supported by Sundari and Susanti (2016), Lo et al. (2010), and Anisyah (2018). Moreover, regarding profitability moderates the effect of tax expense on transfer pricing decisions, the results of the study show that profitability is able to moderate the effect tax expense on transfer pricing decisions. Agency theory explains the difference between the taxpayer or company and tax authorities (Reinganum \& Wilde, 1985). Taxpayers certainly want to get high profits by reducing the tax expense that must be paid by the company. However, the tax authorities want maximum tax revenue by calculating tax revenue in accordance with tax regulations. The existence of a high level of profitability will influence the company to make transfer pricing decisions in order to reduce tax expenses that must be paid. It can be seen that the company has a relatively low effective tax rate. Although the effective tax rate is low, it can influence the company to make transfer pricing decisions because the company has achieved the desired level of profitability. The role of profitability that is able to strengthen the effect of tax expense on transfer pricing decisions can be seen at PT Golden Energy Mines Tbk in 2019. The company has an effective tax rate of 0.334 with a profitability of 0.186 and a transfer pricing of 0.117 . With the existence of a high level of profitability, the company makes a high transfer pricing decision due to the influence of the role of profitability even though the effective tax rate is low. Hypothesis testing results also showed that profitability is not able to moderate the influence bonus mechanism on transfer pricing decision. This means that companies with a high level of profitability will not make transfer pricing decisions to obtain bonuses from company owners. Bonus plan hypothesis is one of which described accounting positive theory the relationship between bonus and profit. Watts \& Zimmerman (1986) explains that manager companies with bonus mechanisms tend to be choosing the procedure of accounting with changes in earnings are reported on a period of ahead to a period of the present. The management of the company wants the results of its performance to be considered good by the owner of the company so the bonus that the management gets will be more. The management prefers the level of transfer pricing that is much lower to avoid changes in reported net profit increase. Company management is less effective in increasing company profits if bonuses are given to managers based on the level of increase in overall net income. Then, companies that have a high level of profitability tend not to make transfer pricing decisions with the aim of obtaining the maximum bonus from the company owner. This can be seen in PT Mitrabara Adiperdana Tbk in 2017 period which had a high level of profitability and implemented a bonus mechanism, but the company did not make transfer pricing decisions even though its profitability was high.

Lastly, regarding profitability moderates the effect of tunneling incentive on transfer pricing decisions, the results of the study showed that the profitability is not capable of moderation effect tunneling incentive on transfer pricing decisions. This means that companies that have a high level of profitability tend not to make transfer pricing decisions when share ownership is dominated by foreign parties. Agency theory explains there were differences between majority shareholders as agent and minority shareholders as principal (Jafri \& Mustikasari, 2018). Majority shareholders of which have more information than minority shareholders will be easier to control the management company. However, majority shareholders who are dominated by foreign parties do not use their controlling rights to make transfer pricing decisions (Saifudin \& Putri, 2018). Majority shareholders tend to want their companies to earn high profits and still distribute dividends to minority shareholders. Then, companies with high levels of profitability tend to be less effective in making transfer pricing decisions when the majority shareholder is controlled by foreign parties. It can be seen in 2019 PT Bayan Resources Tbk which has a high level of profitability and shareholders are dominated by foreign parties, but the company did not make a transfer pricing decision. 
The results showed that the activities of tunneling incentive may increase in the company when the majority shareholding in controlled by foreign parties is high. The company took transfer pricing decisions to reduce the tax expense and maximize profits when the company's high-level profitability. Tax expense and bonus mechanism variables have no effect on transfer pricing decisions and profitability is unable to moderate the effect of bonus mechanisms and tunneling incentives on transfer pricing decisions. The limitation of this study is that the companies used by the research sample have suffered losses so that they do not fall within the specified sample selection criteria. This becomes the writer's limitation because of the limited number of samples that can be used in this study. Suggestions for further research, can add samples of other sector companies so that the results can be better.

\section{References}

Agana, J. A., Mohammed, A. K., \& Zamore, S. (2018). International Transfer Pricing and Income Shifting in Developing Countries: Evidence from Ghana. International Journal of Emerging Markets, 8(1), 1-38.

Agregasi. (2015). Praktik Transfer Pricing Sebabkan Indonesia Rugi Rp100 T. https://economy.okezone.com/read/2015/09/16/20/1215476/praktik-transfer-pricing-sebabkan-indonesia-rugi-rp100-t (Diakses 10 Februari 2020).

Alfandia, N. S. (2018). Pajak dan Struktur Modal Perusahaan Manufaktur di Indonesia. Jurnal Berkala Akuntansi Dan Keuangan Indonesia, 3(1), 17-34.

Alino, N. U., \& Lane, S. (2015). A Conceptual Model of the Effects of Taxation, Exchange Rate, and Regulations on the Transfer Pricing Behavior of Multinational Firm Managers. Journal of Comparative International Management, 18(1), 24-36.

Ang, J. S., Cole, R. A., \& Lin, J. W. U. H. (2000). Agency Cost \& Ownership Structure. The Journal of Finance, 55(1), 81106.

Anisyah, F. (2018). Pengaruh Beban Pajak, Intangible Assets, Profitabilitas, Tunneling Incentive Dan Mekanisme Bonus Terhadap Transfer Pricing (Studi Empiris Pada Perusahaan Manufaktur Yang Listing di BEI Periode 2014-2016). JOM Fekon, 1(1), 1-14.

Chan, K. H., Mo, P. L. L., \& Tang, T. (2016). Tax Avoidance and Tunneling: Empirical Analysis from An Agency Perspective. Journal of International Accounting Research, 15(3), 49-66.

Ghozali, I. (2016). Aplikasi Analisis Multivariete dengan Program IBM SPSS 23 (Edisi 8). Semarang: Badan Penerbit Universitas Diponegoro.

Graham, J. R., Hanlon, M., Shevlin, T., \& Shroff, N. (2017). Tax Rates and Corporate Decision-making. The Review of Financial Studies, 30(9), 1-48.

Hartati, W., Desmiyawati, \& Julita. (2015). Tax Minimization, Tunneling Incentive dan Mekanisme Bonus terhadap Keputusan Transfer Pricing Seluruh Perusahaan yang Listing di Bursa Efek Indonesia. Jurnal SNA Medan.

Hidayat, W. W., Winarso, W., \& Hendrawan, D. (2019). Pengaruh Pajak dan Tunneling Incentive Terhadap Keputusan Transfer Pricing Pada Perusahaan Pertambangan yang terdaftar di Bursa Efek Indonesia (BEI) Periode 2012-2017. Jurnal Ilmiah Akuntansi Dan Manajemen (JIAM), 15(1), 49-59.

Jafri, H. E., \& Mustikasari, E. (2018). Pengaruh Perencaan Pajak, Tunnneling Incentive dan Aset Tidak Berwujud Terhadap Perilaku Transfer Pricing pada Perusahaan Manufaktur yang Memiliki Hubungan Istimewa yang Terdaftar di Bursa Efek Indonesia Periode 2014-2016. Berkala Akuntansi Dan Keuangan Indonesia, 3(2), 63-77.

Jensen, M. C., \& Meckling, W. H. (1976). Theory of The Firm: Managerial Behavior, Agency Costs and Ownership Structure. Journal of Financial Economics, 3, 305-360.

Khasanah, I. (2015). Pengaruh Kompensasi Manajemen Eksekutif Terhadap Kinerja Keuangan Perusahaan. Jurnal Akuntansi UNESA, 20(1).

Lo, A. W. Y., Wong, R. M. K., \& Firth, M. (2010). Tax, Financial Reporting, and Tunneling Incentives for Income Shifting: An Empirical Analysis of The Transfer Pricing Behavior of Chinese-Listed Companies. Journal of the American Accounting Association, 32(2), 1-26.

Nuradila, R. F., \& Wibowo, R. A. (2018). Tax Minimization sebagai Pemoderasi Hubungan antara Tunneling Incentive, Bonus Mechanism dan Debt Convenant dengan Keputusan Transfer Pricing. Journal of Islamic Finance and Accounting, 1(1), 6376.

Rachmat, R. A. H. (2019). Pajak, Mekanisme Bonus dan Transfer Pricing. Jurnal Pendidikan Akuntansi \& Keuangan, 7(1), 2130.

Reinganum, J. F., \& Wilde, L. L. (1985). Income Tax Compliance in A Principal-Agent Framework. Journal of Public Economics, 26, 1-18.

Richardson, G., Taylor, G., \& Lanis, R. (2013). Determinants of Transfer Pricing Aggressiveness: Empirical Evidence from Australian Firms. Journal of Contemporary Accounting and Economics, 9, 136-150.

Saifudin, \& Putri, L. S. (2018). Determinasi Pajak, Mekanisme Bonus, dan Tunneling Incentive terhadap Keputusan Transfer Pricing pada Emiten BEI. Jurnal Ekonomi Dan Bisnis, 2(1), 32-43. 
Septiyani, R. P. P., Ramadhanti, W., \& Sudibyo, Y. A. (2018). Some Factors That Affect Transfer Pricing Decision. SAR (Soedirman Accounting Review): Journal of Accounting and Business, 3(1), 21-38.

Sundari, B., \& Susanti, Y. (2016). Transfer Pricing Practices: Empirical Evidence from Manufacturing Companies in Indonesia. Asia-Pacific Management Accounting Journal, 11(2), 25-39.

Susanti, A., \& Firmansyah, A. (2018). Determinants of Transfer Pricing Decisions in Indonesia Manufacturing Companies. Jurnal Akuntansi \& Auditing Indonesia, 22(2), 81-93.

Thomas, V. F. (2019). Dugaan Adaro Menghindari Pajak Mengingatkan pada Kasus Asian Agri. https://tirto.id/dugaan-adaromenghindari-pajak-mengingatkan-pada-kasus-asian-agri-edHZ (Accessed February 11, 2020).

Utama, C. A. (2015). Penentu Besaran Transaksi Pihak Berelasi: Tata Kelola, Tingkat Pengungkapan, dan Struktur Kepemilikan. Jurnal Akuntansi Dan Keuangan Indonesia, 12(1), 37-54.

Watts, R. L., \& Zimmerman, J. L. (1986). Positive Accounting Theory. Englewood Cliffs, New Jersey: Prentice Hall, Inc.

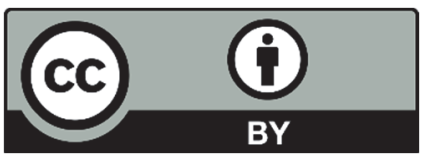

(C) 2021 by the authors; licensee Growing Science, Canada. This is an open access article distributed under the terms and conditions of the Creative Commons Attribution (CC-BY) license (http://creativecommons.org/licenses/by/4.0/). 